\title{
Wave Velocity in the Upper Mantle below the Arctic-Atlantic Ocean and Northwest Europe
}

\author{
Ersteinn TRYgGvason (*) \\ Ricevuto il 27 Ottobre 1961
}

\section{INTRODUCTION}

The structure of the Mid-Atlantic Ridge is characterized by a thin surface layer, probably of volcanic origin, overlying a thick layer with $P$-wave velocity about $7.4 \mathrm{~km} / \mathrm{sec}$ (Ewing and Ewing 1959, Tryggvason 1961). In Iceland the structure is similar, but a layer of some $15 \mathrm{~km}$ thickness and with $P$-wave velocity about $6.7 \mathrm{~km} / \mathrm{sec}$ lies between the two layers of the Mid-Atlantic Ridge (Tryggvason 1959, Båth 1960). It is supposed that the structure of the Mid-Atlantic Ridge extends into the Arctic-Atlantic Ocean in the vicinity of the Mid-Atlantic-Arctic Seismic Belt.

The present paper aims to solve the problems about the thickness and horizontal extension of the 7.4-layer in the Arctic-Atlantic Ocean between Iceland and Spitzbergen, by use of refracted body waves from earthquakes in this region. Furthermore, the upper mantle velocity in northwest Europe is studied by using records of the same earthquakes.

\section{EARTHQUAKES USED}

For our purpose four relatively large earthquakes in the ArcticAtlantic region are selected, and their epicenters and origin times determined as exactly as published observational data permit (ISS 1951, ISS 1952 and Bulletin Mensuel du Bureau Central International de Séismologie).

$\left(^{*}\right)$ On leave from Vedurstofan, Reykjavik, Iceland. 
Only stations at distances greater than $20^{\circ}$ are used in determining the epicenters, as at nearer stations, possible upper mantle anomalies may cause anomalous travel times for the body waves. The traveltime tables of Jeffreys and Bullen (1940) for surface focus are used. The determined epicenters and origin times of these earthquakes are given in Table $\mathrm{I}$.

Table I - Earthquakes USED IN The PRESent STudy

\begin{tabular}{|c|c|c|c|c|}
\hline Date & $\begin{array}{l}\text { Origin time } \\
\quad G M T\end{array}$ & Epicenter & $\begin{array}{l}\text { Assumed } \\
\text { depth km }\end{array}$ & Magnitude \\
\hline 1951, June 6 & $\begin{array}{lll}16 & 10 & 47\end{array}$ & $71.4^{0} \mathrm{~N} \quad 10.1^{0} \mathrm{~W}$ & 10 & $(61 / 2)$ \\
\hline 1952, Dec 10 & $\begin{array}{lll}05 & 58 & 05\end{array}$ & $71.0^{\circ} \mathrm{N} \quad 6.8^{\circ} \mathrm{W}$ & 10 & $(61 / 4)$ \\
\hline 1958, Jan 23 & $13 \quad 3503$ & $65.2^{\circ} \mathrm{N} \quad 6.8^{\circ} \mathrm{E}$ & 10 & $(51 / 2)$ \\
\hline 1959 , Jan 29 & 232431 & $71.0^{\circ} \mathrm{N} \quad 7.2^{\circ} \mathrm{E}$ & 30 & $\left(6 \frac{1}{4}\right)$ \\
\hline
\end{tabular}

The travel times of the first arrived waves at near stations are plotted against epicentral distance in Fig. 1-4 by using a reduced time scale. The time scale is chosen such that the observations on the European continent at epicentral distances between $5^{\circ}$ and $15^{\circ}$ lie near a horizontal line on the figures. This is obtained by subtracting $13.3 \Delta \mathrm{sec}$ from the observed travel time, where the distance $\Delta$ is measured in degrees of arc. The apparent velocity corresponding to a horizontal line on these figures is $8.36 \mathrm{~km} / \mathrm{sec}$.

\section{FOCAL DEPTH}

The focal depth is of great importance in a study like this and should be exactly determined. The observed travel times of $P$-waves at epicentral distances greater than $20^{\circ}$ do not indicate any appreciable focal depth.

For the earthquake of 1951, June 6 , a depth of $60 \mathrm{~km}$ was suggested by U.S.C.G.S., Washington, and B.C.I.S., Strasbourg, and $50 \mathrm{~km}$ by J.S.A., St. Louis. These suggestions are obviously based on $p P-P$ intervals as given by 18 seismograph stations (ISS 1951). If the depth of $60 \mathrm{~km}$ is true, the origin time is some $7 \mathrm{sec}$ later than given in Table I (Jeffreys and Bullen 1940). Observations at near stations as Scoresby- 
sund, Bergen and Uppsala are definitely too early for so late origin time (Fig. 1). Furthermore, surface waves were recorded with large amplitudes in relation to the body wave amplitudes, which indicates shallow focus (e. g. at Pasadena, local bulletin). For these reasons no suggestion is here made regarding the focal depth of this earthquake, but its origin time is tentatively based on the assumed depth of $10 \mathrm{~km}$ (Table I).

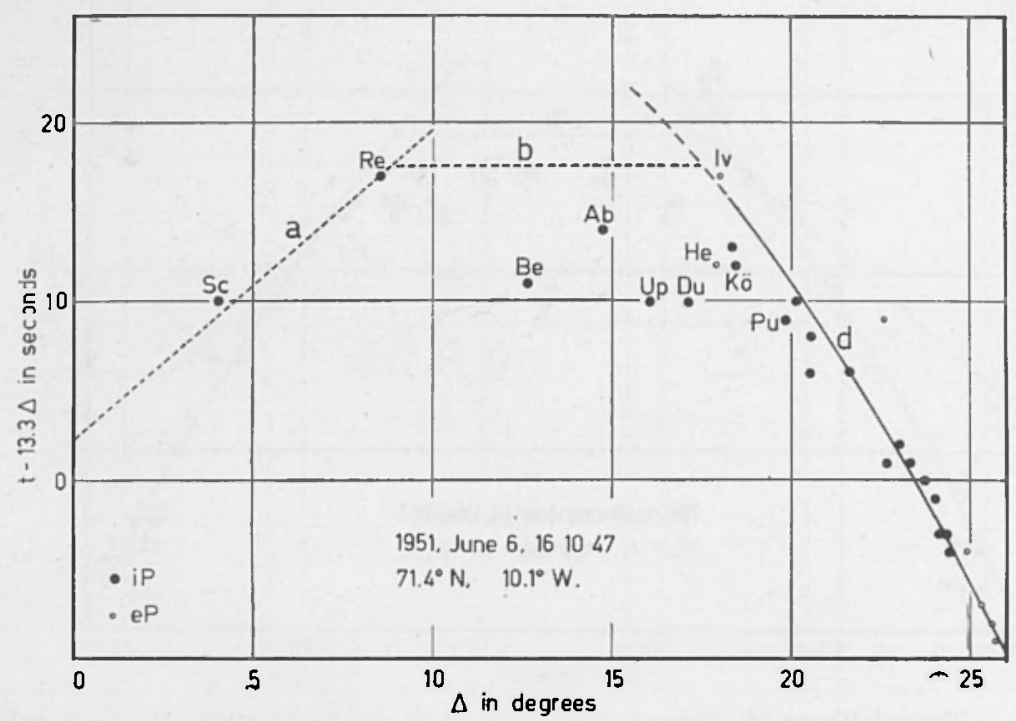

Fig. 1 - Travel times of $P$ waves from the earthquake of 1951, June 6, and adopted travel time curve for oceanic paths. [Abbreviations used in Fig. 1-4. Ab: Aberdeen (Great Britain), Ak: Akureyri (Iceland), Ap: Apatity (U.S.S.R.), Be: Bergen (Norway), Du: Durham (Great Britain), Gb: Goteborg (Sweden), He: Helsinki (Finland). Is: Isfjord (Spitzbergen), Iv: Ivigtut (Greenland), Kh: Kheis (U.S.S.R.), Ki: Kiruna (Sweden), Kö: Kobenhavn (Denmark), No: Nord (Greenland), $\mathrm{Nu}$ : Nurmijärvi (Finland), Pu: Pulkovo (U.S.S.R.), Re: Reykjavik (Iceland), Sc: Scoresbysund (Greenland), Si: Sida (Iceland), Sk: Skalstugan (Sweden), So: Sodankylä (Finland), Up: Uppsala (Sweden)].

The focal depth of the earthquake of 1952, December 10, cannot be determined by use of travel time data. No $p P$ are observed (ISS 1952). The $P$-waves at distances between $10^{\circ}$ and $20^{\circ}$ are usually somewhat later than for the earthquake of 1951, June 6 (Fig. 2), which indicates a greater focal depth. Large surface waves indicate shallow focus. The origin time given in Table $I$ is based on the assumed depth of $10 \mathrm{~km}$. 
Data about the earthquakes of 1958, January 23, and 1959, January 29, are given in Bulletin Mensuel du B.C.I.S., Strasbourg, without any estimates of the focal depth. The observations at near stations, lowever, indicate deeper focus for the latter (Fig. 3 and 4). From the Jeffreys and Bullen (1940) tables for surface focus, we find the time intercept for branch $c$ of the travel time curve to be 7.4 sec for the first

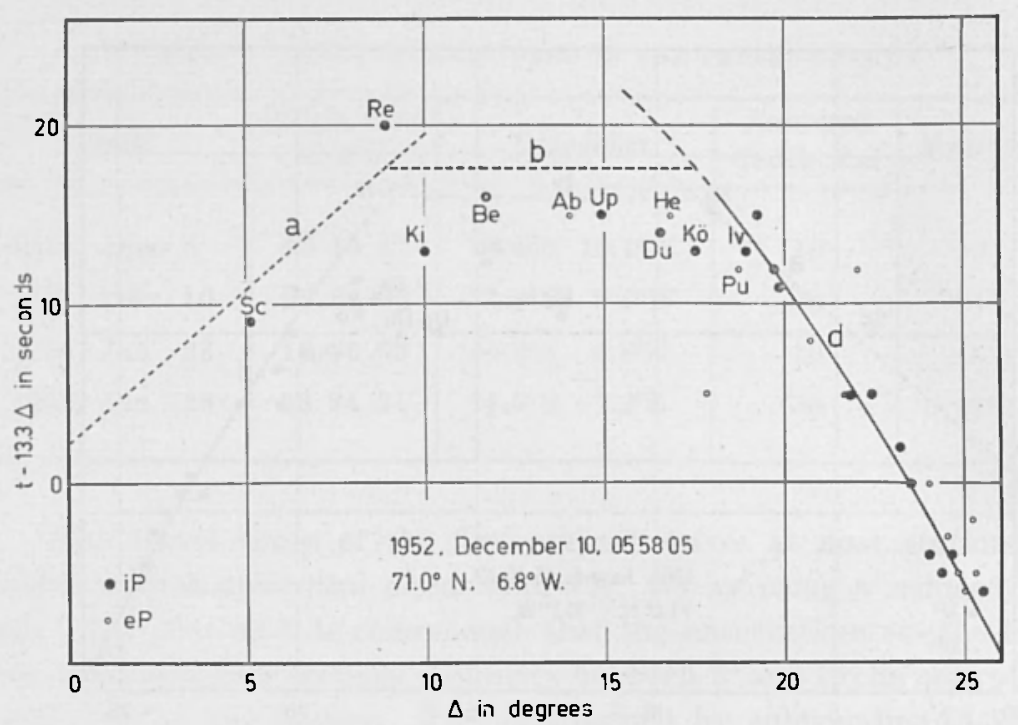

Fig. 2 - Travel times of $P$ waves from the earthquake of 1952 , December 10 and adopted travel time curve for oceanic paths.

against 11.4 sec for the latter earthquake. This difference can be explained by a difference of some $35 \mathrm{~km}$ in the focal depth, but it can also be explained by different upper mantle wave velocity in the vicinity of the epicenters. Tentatively, difference in focal depth is set to $20 \mathrm{~km}$ and the focal depth of the first is set to $10 \mathrm{~km}$, which is only a rough estimate. The error in the focal depth, however, has small influence on the present result as regards the difference between continental and oceanic structure.

\section{Travel times of $P$ waves}

Looking at Fig. 1-4 we clearly observe that the first arrivals at stations in Greenland and Iceland are delayed as compared with the European continent. Because of this we have constructed two different 
travel time curves, shown on the figures, one representing the oceanic paths (branch $a$ and $b$ ) and another representing continental paths (branch c).

The oceanic travel time curve is constructed from the observational data of the seismograph stations in Greenland, Iceland and Spitzbergen and a wave velocity of $7.4 \mathrm{~km} / \mathrm{sec}$ (branch $a$ ) is assumed at short epicentral

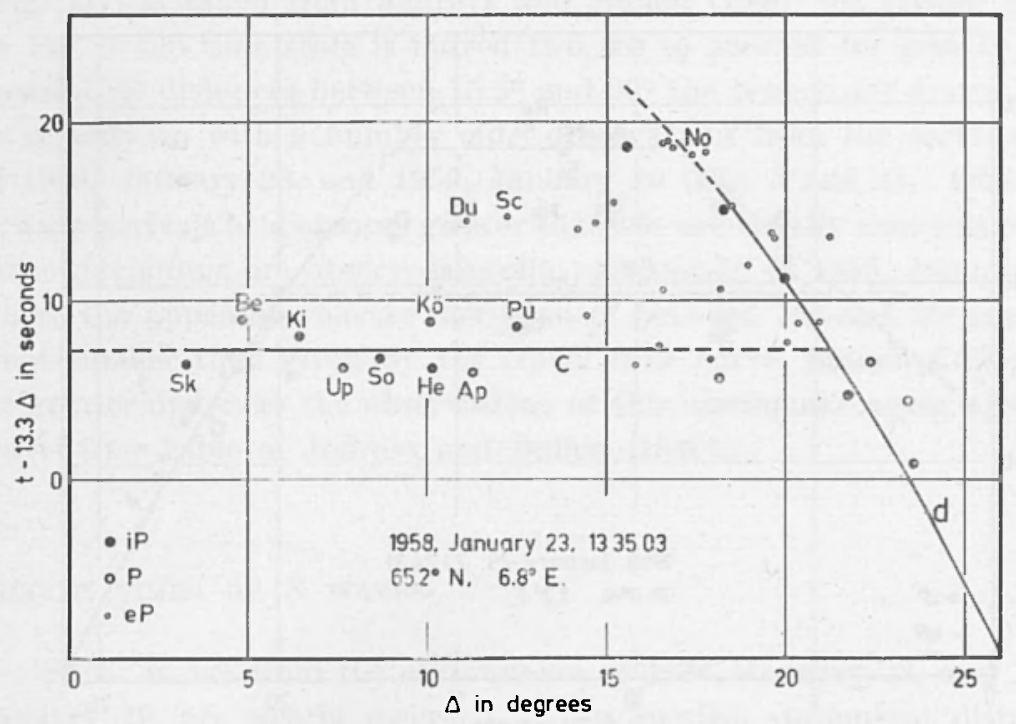

Fig. 3 - Travel times of $P$ waves from the earthquake of 1958, January-23, and adopted travel time curve for continental paths.

distances in agreement with previous observations. The apparent velocity of $P$ waves between Scoresbysund and Reykjavik for the two first earthquakes (Fig. 1 and 2) is 7.47 and $7.11 \mathrm{~km} / \mathrm{sec}$ respectively. This indicates that the apparent velocity of about $7.4 \mathrm{~km} / \mathrm{sec}$ is valid for distances up to about $1000 \mathrm{~km}$ and that the origin times of these earthquakes are very near those given in Table $I$. The time intercept of the 7.4 branch is about 2 sec, a value expected for a focus in the 7.4layer, if the crustal structure is as found in Iceland (Bath 1960). The observed arrival time of $P$-wave at Isfjord, 1959, January 29, agrees with the adopted travel time curve, branch $a$ (Fig. 4).

Observations of $P$ waves at Icelandic stations and at Nord, Greenland, from the earthquake of 1959 , January 29, are too early for the branch $a$ of the adopted travel time curve (Fig. 4). Unfortunately, the $P$ phase was recorded at the end of the paper at Reykjavik. The $P$ 
arrival was probably somewhat ( 1 sec) earlier than the published value. The apparent velocity between Akureyri and Sida is $8.57 \mathrm{~km} / \mathrm{sec}$, between Akureyri and Reykjavik 8.04 (8.30) km/sec and between Sida and Reykjavik $7.39(7.95) \mathrm{km} / \mathrm{sec}$. The values in parentheses are the velocities if the time at Reykjavik is taken one sec earlier than the published value. This indicates an apparent velocity somewhat in excess of

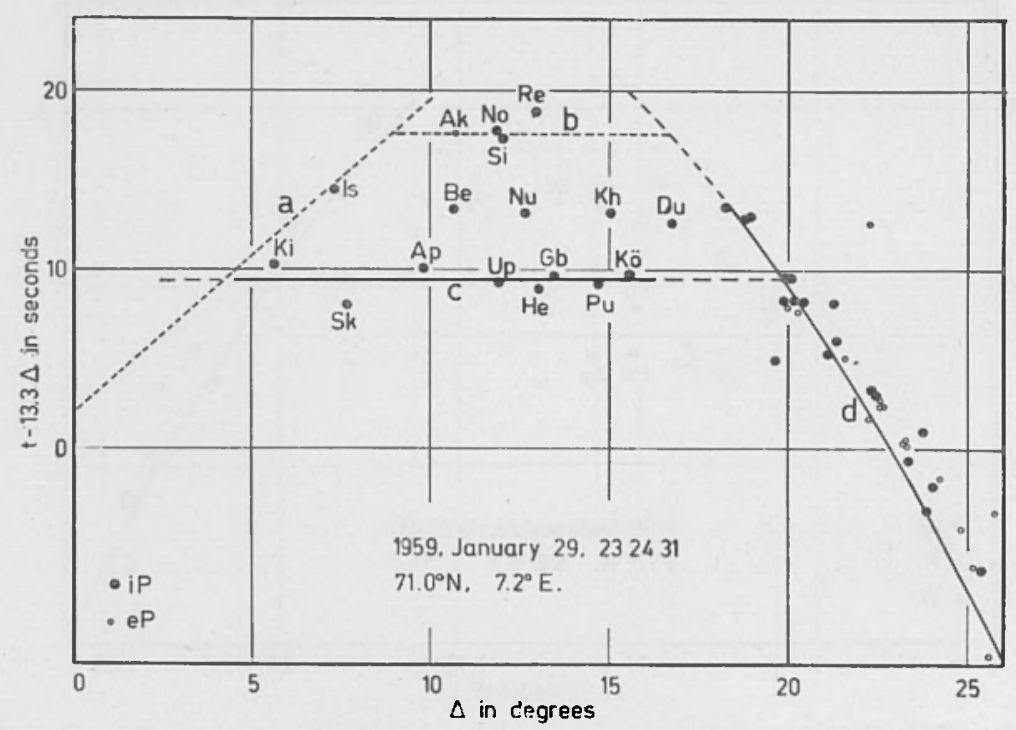

Fig. 4 - Travel times of $P$ waves from the earthquake of 1959, January 29 and adopted travel time curves for oceanic and continental paths.

$8 \mathrm{~km} / \mathrm{sec}$ at distances between 1200 and $1450 \mathrm{~km}$ from the epicenter. The observation at Nord agrees with the Icelandic stations. Branch $b$ on Fig. 1, 2 and 4 represents an apparent velocity of $8.36 \mathrm{~km} / \mathrm{sec}$ which is to be regarded as a maximum value for the velocity at $1200-1400 \mathrm{~km}$ epicentral distance. Because of the low number of observations the velocity cannot be determined accurately.

Observed arrival times of $P$ waves from the two first earthquakes (Fig. 1 and 2), where the main part of the path is across the ocean (Aberdeen, Bergen, Durham and Kiruna) are too early for branch $b$, but this can be explained by the fact, that considerable portions of the paths are along continental structures. However, these observations together with observations at distances between $15^{\circ}$ and $20^{\circ}$ indicate, that branch $b$ is not correctly represented by a straight line, but should 
rather be curved and merge into branch $d$ at some $20^{\circ}$ to $22^{\circ}$ epicentral distance.

The continental travel time curve is well defined by observations of the two last earthquakes (Fig. 3 and 4 ) and is characterized by a constant apparent velocity, $8.36 \mathrm{~km} / \mathrm{sec}$, at distances between 500 and $2200 \mathrm{~km}$ (branch $c$ ). Branch $d$ at epicentral distances greater than $20^{\circ}$ (Fig. 1-4) is taken from Jeffreys and Bullen (1940) for surface focus. In Fig. 4 the time scale is moved two sec to account for greater focal depth. At distances between $15.5^{\circ}$ and $20^{\circ}$ the branch $d$ is drawn to be in accordance with a number of $P$ observations from the earthquakes of 1958, January 23, and 1959, January 29 (Fig. 3 and 4). Observed $P$ wave arrivals at distances greater than $20^{\circ}$ are usually near this curve. Some deviations are observed for the earthquake of 1959, January 29, where the apparent velocity at distances between $20^{\circ}$ and $25^{\circ}$ is somewhat smaller than given by the travel time curve, branch $d$ (Fig. 4). At greater distances the observations of this earthquake agree with the travel time table of Jeffreys and Bullen (1940).

\section{Travel tumes of $S$ WaVes}

Shear waves from the earthquakes of 1958, January 23, and 1959 , January 29, are clearly recorded at the Swedish stations at distances between $5^{\circ}$ and $13.5^{\circ}$. The apparent $S$-wave velocity is $4.73 \pm 0.12$ $\mathrm{km} / \mathrm{sec}$ as computed from records of the latter earthquake and about $4.68 \mathrm{~km} / \mathrm{sec}$ for the first one. By excluding stations where the commencement of the $S$-waves is greatly disturbed by the preceding wave motion, we get an apparent $S$-wave velocity of $4.70 \pm 0.02 \mathrm{~km} / \mathrm{sec}$ across Sweden, with a time intercept of about 12 sec. This velocity is somewhat higher than found by Lehmann (1961) below the N. American and European continents.

For the oceanic paths, clear $S$-wave records are few. At Sida, 1959, January 29, we have a clear $S$ some 18 sec later than at the same distance along the continental paths. Faint $S$ waves with indefinite commencement are also recorded at Akureyri and Reykjavik from the same earthquake, but at Nord no trace of $S$-waves is seen on the vertical seismograph record, although the epicentral distance and the instrumentation is the same as at Sida. These few observations do not permit any determination of the $S$-wave travel-time curve across the Arctic-Atlantic Ocean. 


\section{UPPER MANTLE STRUCTURE}

The observed travel times along oceanic paths (branch $a$ and $d$ on Fig. 1, 2 and 4) can be produced by crustal and upper mantle structure as follows (Fig. 5).

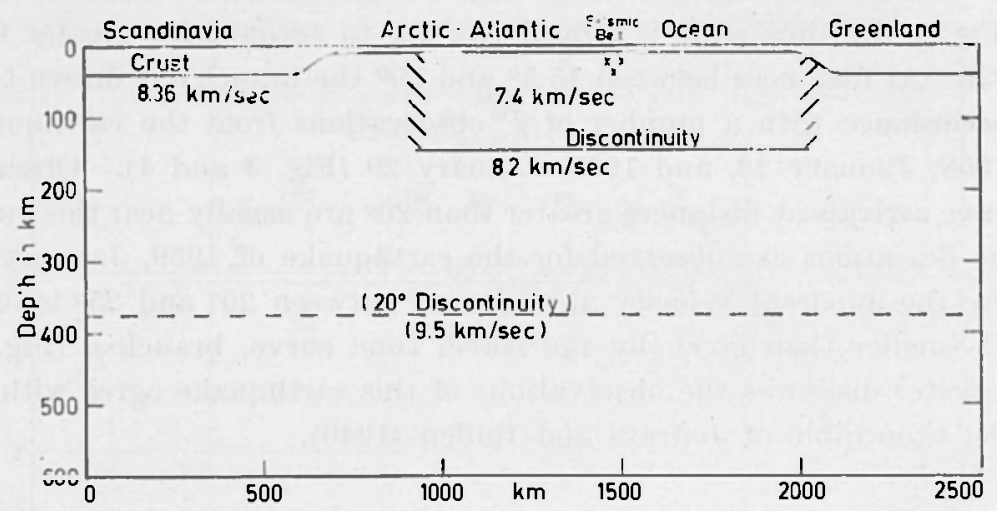

Fig. 5 - Vertical section across the Arctic-Atlantic Ocean from Scandinavia to Greenland, showing $P$-wave velocities as found in the present study and approximate extension of the 7.4-layer.

Below a crustal layer, assumed $10 \mathrm{~km}$ thick, there is a layer with $P$-wave velocity about $7.4 \mathrm{~km} / \mathrm{sec}$. This layer, if assumed homogeneous, is about $130 \mathrm{~km}$ thick. At a depth of $140 \mathrm{~km}$ the $P$-wave velocity jumps to some $8.2 \mathrm{~km} / \mathrm{sec}$ at a surface here named the $7.4 / 8.2$ discontinuity.

The accuracy of this picture is unfortunately low because of too few observations. The $7.4 / 8.2$ discontinuity does not need to be sharp; a rapid increase in the velocity with depth will produce a similar travel time curve. The $P$-wave velocity just below the discontinuity is also inaccurate, probably not higher than $8.2 \mathrm{~km} / \mathrm{sec}$, but may be some 0.2 $\mathrm{km} / \mathrm{sec}$ lower. This inaccuracy makes the depth of the 7.4/8.2 discontinuity also inaccurate, and the mentioned depth of $140 \mathrm{~km}$ should be regarded as a maximum depth, as it is computed on basis of the highest probable velocity below the discontinuity. The lowest probable depth of the $7.4 / 8.2$ discontinuity is about $100 \mathrm{~km}$.

Below the $7.4 / 8.2$ discontinuity the $P$-wave velocity cannot be determined in the oceanic region here studied, because of insufficient 
observations. There are, however, some indications of a low-velocity layer below this discontinuity, as earthquakes in the Arctic-Atlantic Ocean at distances between $10^{\circ}$ and $15^{\circ}$ are rarely recorded at Icelandic stations.

The apparent $P$-wave velocity in northwest Europe (branch $c$ in Fig. 3 and 4) is $8.36 \mathrm{~km} / \mathrm{sec}$, which is a rather high value for the upper mantle velocity (Gutenberg 1959 b, Steinhart and Meyer 1961, Båth 1961). If the crustal thickness decreases away from the epicenters, the apparent velocity is higher than the true upper mantle velocity. For 0.5 slope of the Mohorovicic discontinuity the difference between the apparent and the true velocity is some $0.06 \mathrm{~km} / \mathrm{sec}$, and this means, that the earth's crust is $10 \mathrm{~km}$ thinner at $15^{\circ}$ epicentral distance than at $5^{\circ}$ distance. Greater slope is not probable in the region concerned, so the true upper mantle $P$-wave velocity is probably more than $8.30 \mathrm{~km} / \mathrm{sec}$, but less than $8.36 \mathrm{~km} / \mathrm{sec}$.

Amplitudes of $P$-waves of the earthquakes here considered have not been studied in order to find a shadow zone at short distances. Gutenberg (1954) found, that in the great Kern County earthquake of 1952 , the observed $P$ arrivals at distances between $6^{\circ}$ and $16^{\circ}$ were delayed compared with observations at shorter distances, in spite of an excellent network of stations equipped with first class seismographs. Similar delay is not observed in our case and according to Lehmann (1954) such a delay has never been observed in Europe.

\section{Discussion}

The oceanic layer having $P$-wave velocity about $7.4 \mathrm{~km} / \mathrm{sec}$ is here found to be more than $100 \mathrm{~km}$ thick. At the base of this the velocity increases to some $8.2 \mathrm{~km} / \mathrm{sec}$, a value frequently found just below the Mohorovičic discontinuity. The 7.4/8.2 discontinuity may possibly be taken as the Mohorovicic discontinuity (the base of the crust), but its great depth makes the writer prefer a definition such that the 7.4-layer belongs to the mantle.

The structure here classified as oceanic is different from that generally found below the deep oceans (Ewing, Jardetzky and Press 1957, Gutenberg 1959 a; Dorman, Ewing and Oliver 1960), and is apparently related to the Mid-Atlantic Ridge and the Mid-Atlantic Seismic Belt. It probably forms a broad zone of low-velocity upper mantle along the whole Atlantic Ocean. The width of this low-velocity zone cannot be 
determined exactly from the present data, but by comparison with refraction measurements at sea (Ewing and Ewing 1959) we obtain a probable width of $1000 \mathrm{~km}$. However, our data do not exclude the possibility, that the upper mantle low-velocity region covers the whole oceanic area between Greenland and Norway.

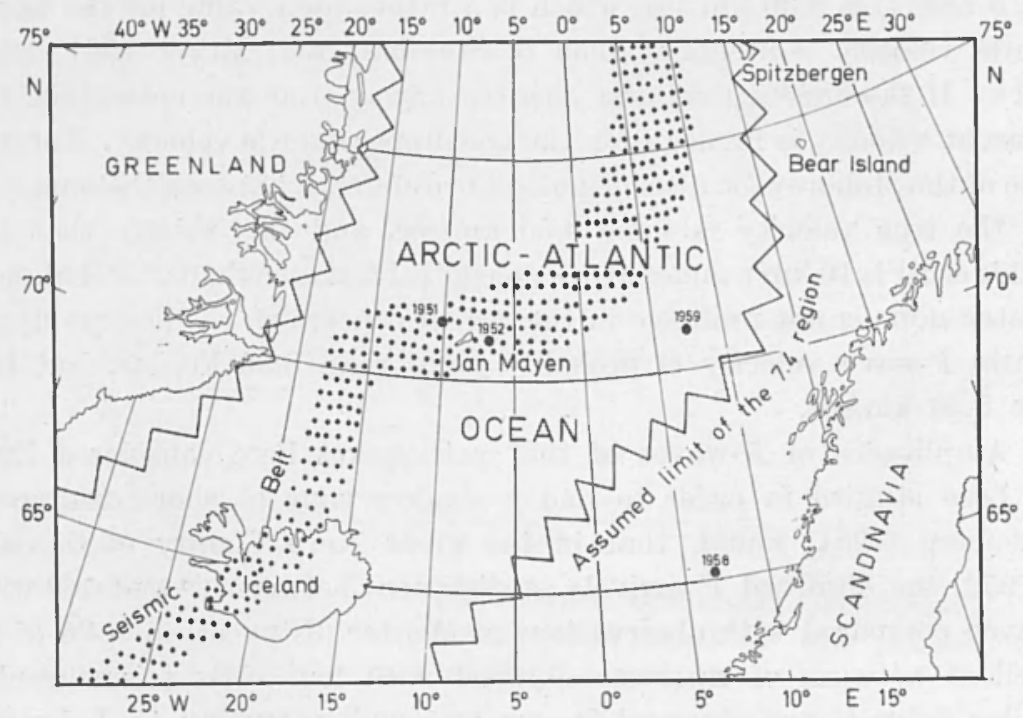

Fig. 6 - Map showing epicenters of the earthquakes selected for the study, indicated by the year of occurrence, and assumed limits of the lowvelocity upper mantle (7.4-region). The seismic belt is indicated as given by Tryggvason (1955).

Fig. 6 gives a map of the Arctic-Atlantic Ocean, showing the MidAtlantic Seismic Belt through the region (Tryggvason 1955) and the probable limits of the low-velocity zone in the upper mantle, some 1000 $\mathrm{km}$ broad. This limit is partly obtained from travel times of $P$-waves from the earthquakes studied to stations at epicentral distances smaller than $13^{\circ}$ by assuming that the waves have travelled inside the 7.4-layer to its border and thereafter with a velocity of $8.3 \mathrm{~km} / \mathrm{sec}$. A delay of $3.6 \mathrm{sec}$ is assumed because of the crustal layers. Such computations based on the origin times given in Table I give the part of the wave path lying inside the 7.4-region as follows:

$\begin{array}{lrllr}\text { From } 71.4^{\circ} \mathrm{N}, & 10.1^{\circ} \mathrm{W} \text { to } & \text { Bergen } & 450 \mathrm{~km} \\ \text { From } 71.0^{\circ} \mathrm{N}, & 6.8^{\circ} \mathrm{W} \text { to Kiruna } & 575 \mathrm{~km} \\ \text { From } 71.0^{\circ} \mathrm{N}, & 7.2^{\circ} \mathrm{E} \text { to Swedish st. } & 300 \mathrm{~km} \\ \text { From } 65.2^{\circ} \mathrm{N}, & 6.8^{\circ} \mathrm{E} \text { to Swedish st. } & 0 \mathrm{~km}\end{array}$


The wave path from $71.4^{\circ} \mathrm{N}, 10.1^{\circ} \mathrm{W}$ and $71.0^{\circ} \mathrm{N}, 6.8^{\circ} \mathrm{W}$ to Reykjavik and Scoresbysund lie wholly inside the 7.4-region according to these computations. The same is true for the path from $71.0^{\circ} \mathrm{N}, 7.2^{\circ} \mathrm{E}$ to Isfjord.

Furthermore, the limits of the 7.4-zone in Fig. 6 are based on its probable width of $1000 \mathrm{~km}$ and on the assumption that its limits are rouglily parallel to the Mid-Atlantic Seismic Belt.

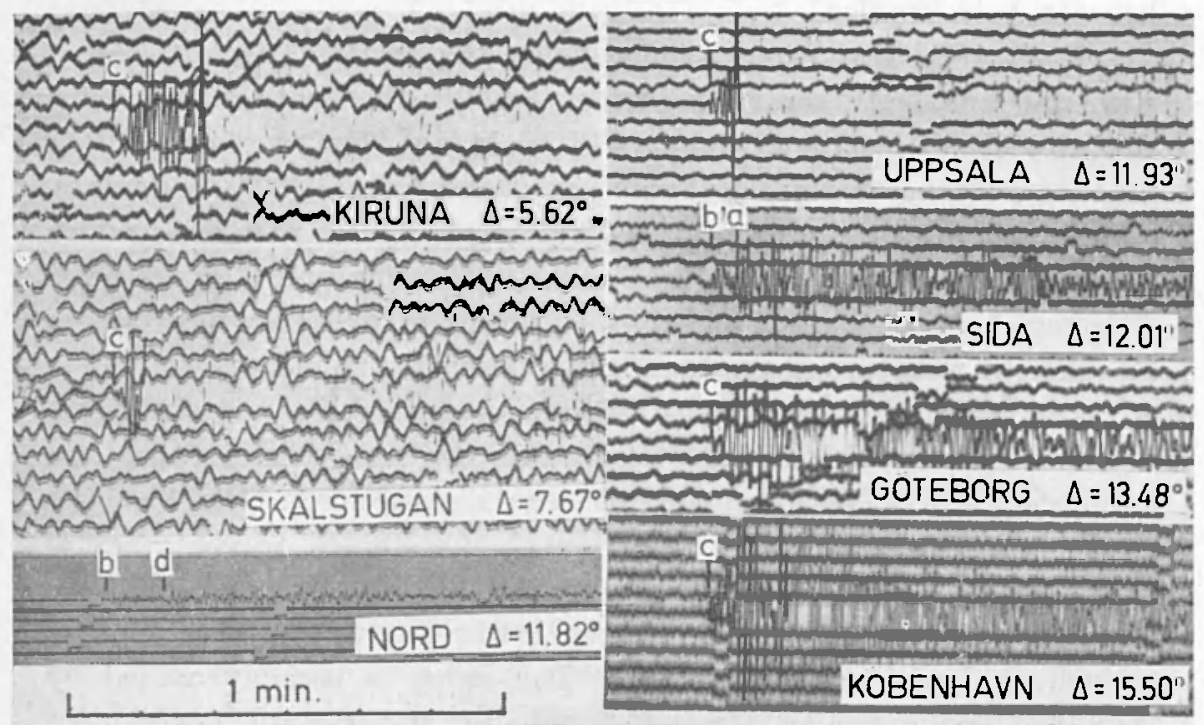

Fig. 7 - Records of $P$-waves of the earthquake of 1959, January 29 , at $5.6^{\circ}$ to $15.5^{\circ}$ epicentral distance. The letters $a$. $b$. $c$ and $d$ refer to the branches of the travel time curves of Fig. 4.

Somewhere near the border of the continental crustal structure off the Norwegian coast, the upper mantle $P$-wave velocity increases remarkably to $8.3-8.4 \mathrm{~km} / \mathrm{sec}$, which is observed in Scandinavia. Our data do not indicate if this change is gradual or abrupt. The $P$-wave velocity in the upper mantle below northwest Europe probably decreases somewhat with depth, as otherwise the apparent velocity should increase with epicentral distance. The velocity decrease with depth is apparently slight, at least in the top layer of the mantle, as otherwise the amplitudes of the $P$-waves refracted in this layer should decrease rapidly with increasing distance, which is not observed (Fig. 7). 
The thickness of the layers with different wave velocity below the continent and the ocean cannot be determined exactly by using only the present data. Below the "200-discontinuity" (at some $400 \mathrm{~km}$ depth) both regions have apparently the same velocity. However, the amplitudes of the $P$-waves as recorded at Swedish stations are smaller for waves arriving from west (Central America) than for those arriving from east (Southeast Asia), (Båth, personal communication). If this is caused by the root of the Mid-Atlantic Ridge or by some other reason has not been studied.

The 7.4/8.2 discontinuity found below the Arctic-Atlantic Ocean at some $140 \mathrm{~km}$ depth cannot be detected below the continent by using the present observational data. This does not, however, exclude its possible existence there. Hoffman, Berg and Cook (1961) found indications of reflected energy from $190 \mathrm{~km}$ depth in western U.S.A., which possibly may be related to the $7.4 / 8.2$ discontinuity. The observed difference between oceanic and continental travel times may be produced by different structure above the 7.4/8.2 discontinuity alone.

The depth of the structural difference below oceans and continents here considered can probably be studied by using travel times and amplitudes of $P$-waves at greater epicentral distance or at other localities than in the present work. Båth (1947) has studied travel times of earthquake waves for Uppsala and found indication, although not statistically significant, of a slight delay of $P$-waves from the NW quadrant as compared with other azimuths. This delay is possibly caused by the structural anomalies associated with the Mid-Atlantic Ridge.

\section{ACKNOWLEDGMENTS}

The research reported in this paper has been made possible through the support and sponsorship of the U.S. Department of Army, through its European Research Office (Contract No. DA-91-591-EUC-1637). It was carried out during the author's visit to the Seismological Institute, Uppsala. Dr. Markus Båth, Uppsala, has contributed by many valuable discussions and by reading the manuscript. The directors the of seismological stations Köbenhavn, Nord and Sida contributed by lending seismograms.

I wish to express my sincere thanks to the persons and institutions mentioned. 


\section{SUMMARY}

Travel times of body waves from four earthquakes in the Arctic-Atlantic Ocean are studied. For the oceanic area between Greenland and Norway and north of Iceland, the upper mantle P-wave velocity is $7.4 \mathrm{~km} / \mathrm{sec}$ to a depth of $140 \mathrm{~km}$, where the velocity increases to $8.2 \mathrm{~km} / \mathrm{sec}$. Below this the velocity probably decreases somewhat, but farther down no structural anomaly is observed.

Below northwest Europe the upper mantle has a P-wave velocity of $8.36 \mathrm{~km} / \mathrm{sec}$ and an S-wave velocity of $4.70 \mathrm{~km} / \mathrm{sec}$, which are unusually high values. The velocity decreases somewhat with depth in the top layer of the mantle. At a depth less than $400 \mathrm{~km}$, possibly at $140 \mathrm{~km}$ depth, the difference between the oceanic and continental structure has disappeared.

\section{RIASSUNTO}

Vengono studiati dall' Autore, per mezzo dei dati forniti da quattro terremoti avvenuti nell'Oceano Artico-Atlantico, $i$ tempi di tragitto delle onde spaziali. Per la zona oceanica compresa fra la Groenlandia, Norvegia e l'Islanda Settentrionale, la velocità delle onde $\mathrm{P}$ nel mantello superiore, $\grave{e}$ risultata di $7,4 \mathrm{Km} / \mathrm{sec}$ fino alla profondità di $140 \mathrm{Km}$. A tale profondità la velocità aumenta fino a $8,2 \mathrm{Km} / \mathrm{sec}$. Al di sotto di essa la velocità probabilmente diminuisce di poco, anche se non si è osservata, negli strati inferiori, alcuna anomalia strutturale.

Al di sotto dell'Europa Nord-Occidentale, la velocità nel mantello superiore è di $8,36 \mathrm{Km} / \mathrm{sec}$ per le onde $\mathrm{P}$, e di $4,70 \mathrm{Km} / \mathrm{sec}$ per le onde $\mathrm{S}$, valori che risultano insolitamente elevati. La velocità diminuisce lievemente, con la profondità, nello strato superficiale del mantello.

Ad una profondità inferiore ai $400 \mathrm{Km}$, e forse già alla profondità di $140 \mathrm{Km}$, scompare la diversità fra la struttura oceanica e quella continentale.

\section{REFERENCES}

В̊̊тн M., Travel Times of the Principal Earthquake Waves for Uppsala. "Bull. Geol. Inst. Uppsala" XXXII, 105-129 (1947).

- Crustal Structure of Iceland. "J. Geophys. Research" 65, 1793-1807 (1960).

—Die Conrad-Diskontinuität. "Freiberger Forschungshefte" C 101, 5-34, (1961). 
Dorman J., Ewing M. and OLIver J., Study of Shear-Velocity Distribution in the Upper Mantle by Mantle Rayleigh Waves. "Bull. Seism. Soc. Amer." 50, 87-115, (1960).

EwING J. and Ewing M., Seismic-Refraction Measurements in the Atlantic Ocean Basin, in the Mediterranean Sea, on the Mid-Atlantic Ridge, and in the Norwegian Sea. "Bull. Gool. Soc. Amer." 70, 291-318, (1959).

Gutenberg B., Low-Velocity Layers in the Earth's Mantle. "Bull. Gool Soc. Amer." 65, 337-348, (1954).

- Physics of the Earth's Interior. Academic Press, New York (1959 a).

- Wave Velocities below the Mohorovicic Discontinuity. "Geophys. J.", 2, 348-352 (1959 b).

Hoffman J. P., Berg J. W. Jr. and Cook K. L., Discontinuities in the Earth's Upper Mantle as Indicated by Reflected Se ismic Energy. "Bull. Seism. Soc. Amer.", 51, 17-27 (1961).

Jeffreys H. and Bullen K. E., Seismological Tables. British Ass. for the Advancement of Science (1940).

Lemmann I., The Velocity of $\mathrm{P}$ and $\mathrm{S}$ Waves in the Upper Part of the Earth's Mantle. Publ. Bureau Central Séism. Int., Ser. A, 19, 115-123, (1954).

Lenmann I., S and the Structure of the Upper Mantle. "Geophys. J." 4. 124138 (1961).

Steinifart J. S. and Merer R. P., Explosion Studies of Continental Structure. Carnegie Inst. of Washington, Publ. 622, (1961).

Tryggvason E., Seismicity of Iceland and the Surrounding Oceans. " Natturufraedingurinn"' (Reykjavik) 25, 194-197, (1955).

- Longitudinal Wave Velocity in the Earth's Crust in Iceland. "Nátturufraedingurinn" (Reykjavik) 29, 80-84 (1959).

- Crustal Structure of the Iceland Region from Dispersion of Surface Waves. Submitted for publ. in "Bull. Seism. Soc. Amer." (1961). 